\title{
The Impact of Foreign Direct Investment in the Western Balkan Countries - A Panel Data Analysis
}

\author{
Nexhat Shkodra ${ }^{1}$, Xhevat Sopi $^{1 *}$, Florentina Xhelili Krasniqi ${ }^{2}$ \\ ${ }^{1}$ Faculty of Economics, University of Gjilani "Kadri Zeka", Gjilan 60000, Republic of Kosovo \\ ${ }^{2}$ Faculty of Economics, University of Prishtina "Hasan Prishtina", Pristine 10000, Republic of Kosovo
}

Corresponding Author Email: xhevat.sopi@uni-gjilan.net

https://doi.org/10.18280/ijsdp.160619

Received: 3 May 2021

Accepted: 10 October 2021

\section{Keywords:}

FDI effects, Economic growth, panel data, transition countries, Western Balkans

\begin{abstract}
Foreign Direct Investment (FDI) has a significant effect on the economic growth and development of host economies, but also on international economic integration through globalization. Particular aspects of this topic are being extensively addressed by scientific research in recent decades. The purpose of this paper is to determine whether globalization and through it the Foreign Direct Investment (FDI) has an impact on the economic growth (GDPgr) of the Western Balkan countries which are facing a transitional phase. The relation between FDI and economic growth has been analyzed by employing econometric models with panel data approach: linear regression with poled data, the Fixed Effects model, and the Random-Effects model (GLS). The study is based on panel data of six countries for the period between 2004-2018, obtained by the World Bank. The results of the Random Effects model (GLS) shown that lagged FDI has a significant impact on the economic growth (GDPgr) of the Western Balkans $(\mathrm{p}<0.05 \%)$, as well as gross capital formation (Cap) and government expenditure (Gov) whereas export (Ex) has been excluded from the model. The results also shown that there are significant differences in the factors influencing economic growth among countries in the region (LM Method - Breusch-Pagan test; $\mathrm{p}=0.02455<0.05$ ).
\end{abstract}

\section{INTRODUCTION}

It is broadly evident that FDI has an important impact on the economic growth and development of the host economies, and even more regarding international economic integration and globalization. This integration refers to a transformation of most modern technologies, the increase of managerial and organizational skills, as well as modern marketing techniques [1]. Foreign direct investment is increasingly being stimulated as a result of increased productivity and efficiency in economic growth, both for developing and developed countries. To this end, many countries have designed and continue to promote pro-FDI policies, to increase the flow of FDI in the country [2]. In fact, there are various factors that can affect the potential and risks of business in which they can be influenced by actions in individual locations. Therefore, they can be included in these three broad categories: domestic policy framework in relation to foreign direct investment, business facilitation, and economic motive [3]. Whereas, the economic determinants of FDI can be grouped into three groups which reflect the main motivation of foreign firms to invest in host countries, such as market research, resource research, and efficiency research [4].

However, globalization is manifested in a broader range, be it from the economic, political, social, military, cultural, religious, and environmental points of view. Therefore, all these aspects show a different and inevitable impact on the economy of the host countries. But the economic dimension of globalization involves an extraordinary effect on the level of economic development of a country.
Pekarskiene and Susniene [5], have focused on the economic dimension of globalization and determine economic globalization with regard to economic activities, such as international trade, technic-technologic transfer, capital flows, activities of multinational companies, and migration of people. Globalization is about economic integration, as a process by which markets and production in different countries become interdependent among countries due to the dynamics of trade in goods and services, flows of FDI technology [6].

In the last decade, the third wave of globalization appears with a strong economic connection and mainly from a flow of FDIs. According to OECD [7], globalization includes multidimensional economic and dynamic integration, in which, economic and especially national resources are becoming more fluid at the inter-border level whereas the national economies are becoming more and more interdependent. Foreign direct investment is of interest to all countries, be it for developed, developing, and transition countries. Therefore, these countries represent competition to attract FDI, and especially if they are situated in the same geopolitical area, as is the case with the countries that are subject to this study.

Several studies consider that FDI generates economic growth for the host country [8]. This and other direct and indirect effects (spillovers) are evident in many studies $[9,10]$.

Therefore, FDI has positive effects on increasing a country's domestic competitiveness and affects productivity growth, lower prices, and increased resource efficiency [11]. Moreover, since FDI flows are non-debt-creating, they are a preferred method of financing external current account deficits, especially in developing countries, where these deficits can be 
large and sustained [12]. Zhang [13], has an optimistic point of view regarding the prospects of foreign direct investment for a number of reasons, such as FDIs have positive effects on economic growth, including the domestic market and the international market; the current and ongoing global trend for a better business environment and the search for opportunities at competitive prices; through global competition, companies are encouraged to find the destination at lower costs, etc. Hence the policies of most of the governments of the host economies are oriented towards the creation of conditions for attracting FDIs. To be competitive in attracting FDI, these countries must have a well-prepared workforce, a good macroeconomic environment, and reduce trade barriers [3].

On the other hand, in global terms, world trade in goods remains fragile even though in 2017 it represented an increase of trade at the global level, in which world goods exports reached $\$ 17$ trillion, one trillion more than in 2016. But comparing it with world trade in 2013, when global goods exports amounted to $\$ 19$ trillion, then we see a decrease in value in the years 2014-2017. In structural terms, the export of services has also an oscillation, while there is an increase in value by 2016 ( $\$ 5$ trillion) in 2017 ( $\$ 5.3$ trillion) [14].

According to UNCTAD [14], it is estimated that multinational corporations represent around $80 \%$ of the global trade, including also intermediate goods and services. In 2016 , intermediate trade accounts for about $54 \%$ of global trade.

If we focus on the countries of the region which have gone through a phase of transition followed by many crises and armed conflicts followed by more destruction of resources and capital, FDI is considered a key element that will contribute to the economic growth and development of countries by helping in the necessary structural changes for the long term.

However, various researches [12, 15-19] show that FDI flow is not at a satisfactory level in the Western Balkan countries, Estrin and Uvalic [15] consider the so-called "Balkan effect" which, according to them, this seems to indicate that the unfortunate recent political history of the region, with conflicts, fragmentation and low growth, have exercised a long-lasting and independent effect on their prospects. for receipt of FDI. The break-up of the Yugoslav Federation was followed by a decade of military conflicts - in Slovenia (1991), Croatia (1991-95), Bosnia and Herzegovina (1992-95), Kosovo (1998-99), and Macedonia (2001) (Estrin and Uvalic, 2016) [16].

Despite the low level of FDI flow in transitional countries compared to developing and developed countries, according to the World Investment Report [20], projections show that there is a growing trend of FDI flow, especially in transitional countries. Whereas Wang. Li and Sun [21] estimate that in recent years the FDI scale is shrinking courses, compared to developing economies, developed economies faced violent fluctuations in FDI flow.

On the other hand, Dinh et al. [22] find that FDI capital flows can hinder a country's economic growth in the short run, but they asserted that FDI is an important factor for economic growth in the long run, especially for emerging and developing economies. Several other types of researches [19, 23] shown that FDI did not have an effect on the economic growth of the countries of the region in the same year when the investments took place. Meanwhile Shkodra, Sopi and Pantina [24] have found that in one of the countries in the region, the Republic of Kosovo, FDI has a positive impact on economic growth.

These papers did not consider the subsequent effect of FDI and the data used for FDI are in nominal terms. An innovative part of the work is testing for the effect of wet FDI and which will be deflated.

In this context, the research problem that this paper seeks to shed light on is whether the FDI truly has had a positive effect on the economic growth of the countries in the region, as described in the aforementioned studies.

Consequently, we'll test alternative hypotheses of the cause-effect type that we can formulate as follows:

- $H_{1}:$ FDI has a positive effect on the economic growth of the countries of the (Western Balkans) region

- $\mathrm{H}_{2}$ : There are differences among the countries in the region as regards the factors that influence economic growth, including FDI

\section{PROCEDURES AND METHODS}

\subsection{The model}

Hypothesis testing will be based on econometric models applied in the panel data from timing and cross-section series. Based on the Solow model [25], the impact of the Foreign Direct Investment in the economic growth will be tested in the way that the dependent variable will be the economic growth, whereas as independent variables will be taken FDI, formed a capital and net exports.

Based on the theory which assesses that the FDI effect cannot be noticed in the first year of the investments, then the effect is testing by also using the time lag or lag-un [26-28]. In this way, to test the hypotheses, the pool aggregate model will be used initially, which will enable us to test the effect of FDI on economic growth. To test whether there are differences among countries of the region about the FDI's impact on economic growth, the Fixed-Rate Model and the Case-Based Model (GLS) will be used.

Given that all other variables are deflated respectively all variables were in real terms (constant 2005 US \$) except FDI net inflow which is in the current (BoP, current US \$), according to Dalei [29], we used GDP deflator and make nominal FDI inflow (NFDI) into real FDI inflow (RFDI). We have followed the procedure given in equation 1 , to convert nominal FDI into real FDI [29]:

$$
R F D I=\left(\frac{N F D I}{G D P \text { Deflator }}\right) * 100
$$

In the empirical form the model will have this form:

$$
\begin{gathered}
\operatorname{GDPgr}_{i t}=\beta_{0}+\beta_{1} R F D I_{i t}+\beta_{2} R F D I_{i(t-1)}+\beta_{3} \operatorname{Cap}_{i t} \\
+\operatorname{Gov}_{i t}+E x_{i t}+\varepsilon_{i t}
\end{gathered}
$$

where:

GDPgr - The rate of economic growth;

RFDI - Deflated foreign direct investment;

Cap - Gross capital formation;

Gov - General government final consumption expenditure;

Ex - Export;

$\varepsilon$ - error term;

i - unite (country);

$\mathrm{t}$ - time (year).

The general panel model (pool) will be assessed through the Ordinary Last Square Model. This model has a fixed coefficient, regardless of the individual or the period, and does 
not allow differences in behavior in time between specific individuals or vice versa [27].

Fixed-Rate Model will be assessed with the method of dammy variables, where the hypothesis that is tested is the equality between the individuals' intercepts (constants), by using Fisher's test. In this case, the hypotheses are formulated:

$H_{0}$ : All intercepts of individuals are the same

$H_{1}$ : All intercepts are not the same

Case-Based Model (GLS) assumes that both the intercept and the regress coefficient are the same (constant) for any individual while the term $u_{i}$ changes according to individuals and is part of the term of error $\varepsilon$ it. This model has been tested with LM (Lagrange Multiplier) Method - known as the Breusch-Pagan test. In this case, the hypotheses are formulated as follows:

$H_{0}$ : The variances in the error term are the same $\left(\sigma^{2}=0\right)$ 0)

$H_{1}$ : The variances in the error term are not the same $\left(\sigma^{2} \neq\right.$

For selecting among the two models, the one of Fixed-Rate Model and the other one Case-Based Model, Hausman test is used. In this case, the hypotheses are formulated as follows:

$H_{0}$ : Among the individual effects and regressors in the model there is no correlation

$H_{1}$ : Among the individual effects and regressors in the model there is a correlation

In a case when the $\mathrm{H}_{0}$ has been ruled out then the CaseBased Model is better [27, 28].

As stated above, the flow of model testing will be also similar, whereby the Pool Model will be initially tested and evaluated, and then the Fixed-Rate Model and the Case-Based Model.

So, in order to test the hypotheses raised in this study, these types of models have been shown to be more appropriate and give clearer answers. These models have also been used by Topxhiu and Radoniqi [19], Goschin [30], and Meyer and Shera [31]. Other authors, depending on the hypotheses, have applied other models, such as Granger causality test [13], Vector Autoregressive models VAR [32], etc.

\subsection{The data}

The paper uses secondary data obtained by the World Development Indicators [33] of the World Bank database, for six Western Balkans countries, Albania, North Macedonia,
Kosovo, Montenegro, Serbia, and Bosnia and Herzegovina. The selected data covered a period of 15 years, namely the period 2004 - 2018. It was decided for this period due to constraints on the available data for the Republic of Kosovo, where data on Foreign Direct Investments exist only from 2004 onwards.

\section{RESULTS AND DISCUSSIONS}

\subsection{Descriptive statistics on the economic growth of the Western Balkan countries}

Western Balkans countries face some common features, a history filled with so many conflicts among them, a multiethnic society composition of these countries, with a low level of Gross Domestic Product (GDP) per capita compared to the average of the European Union member states (EU - 28 member states) but with a strategic orientation towards the EU.

According to Żuk and Savelin [34], candidate countries for the EU and potential candidates, in 2016, including all Western Balkan countries, have had low-income levels where the average level was less than $50 \%$ compared to EU 28 member states. The lowest level of GDP per capita in terms of PPP is in Kosovo (26\%) and with a higher level is Montenegro (43\%).

According to the World Bank Group [35], the economic growth of the countries in the region in 2018 has expanded by $3.5 \%$ (see Figure 1). North Macedonia's economy has recovered with economic growth of $2.5 \%$ after restoring investors' confidence. In 2018, Serbia's economy recovered by $3.5 \%$ from $1.9 \%$ in 2017. Kosovo and Albania represent an upward trend of economic growth from $3.8 \%$ in 2017 to $4.2 \%$ in 2018. From 4.3\% in 2017, Montenegro in 2018 represents a slight decrease to $3.8 \%$. Bosnia and Herzegovina continue to have a similar economic growth trend in 2017 by $3.0 \%$, and a $3.2 \%$ increase in 2018 .

\subsection{Results of the general panel model}

The testing of the general panel model was initially conducted with pooled data, in which a series of tests were conducted by using or removing lag-s and by including on the model four independent variables as presented in Eq. (1)

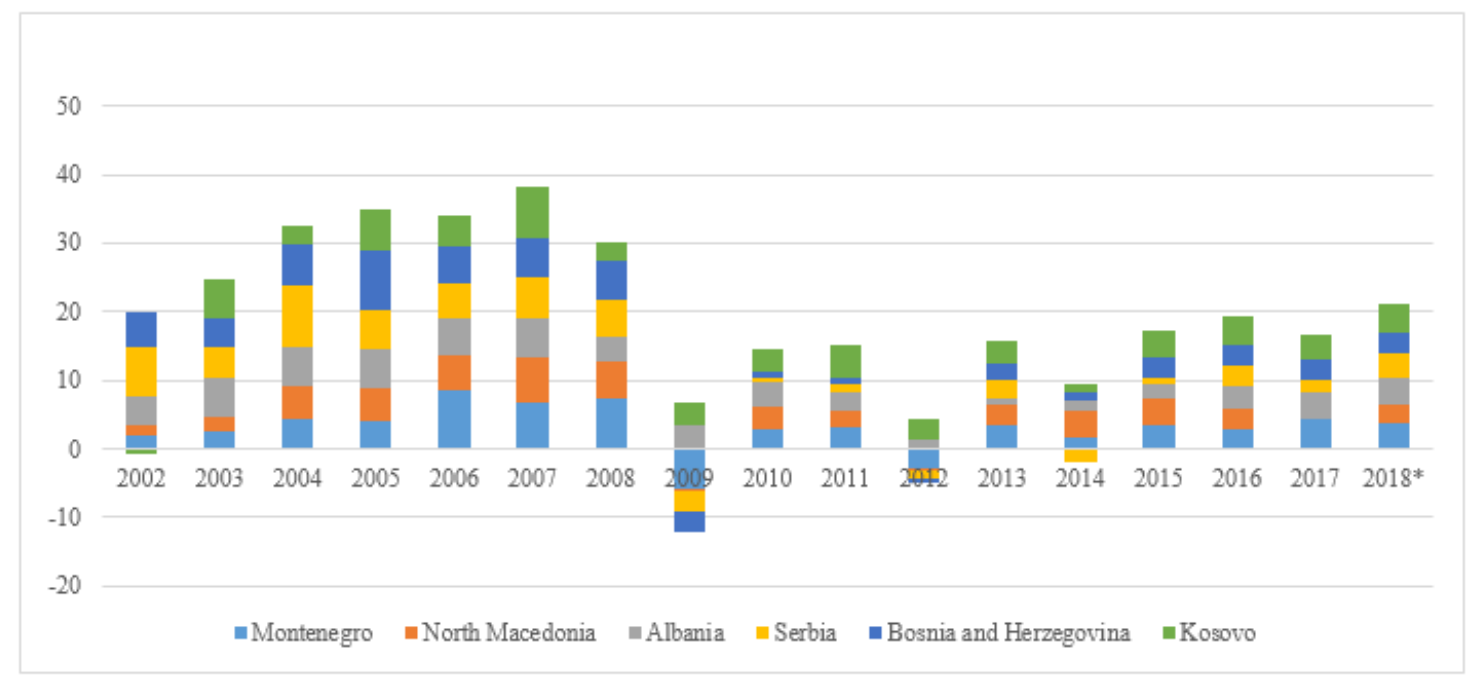

Figure 1. Economic growth of the regional countries, GDP (\% annual), in the years 2002-2018 
As seen in Table 1, the econometric model has relatively a low coefficient of determination, in which the changes in the GDPgr are explained through independent variables at the level of $22 \%$ (R-squared) or according to Adjusted R-squared with $18 \%$. Based on F-test (Fisher Test known as F-Test are used to provide a formal hypothesis test of the overall fit of the model. The null hypothesis in an F-test of overall significance is that all the slope coefficients in the equation equal zero simultaneously (see Studenmund [26]). According to Osmani [27], the F-test used for testing the general panel model with pooled data as well) the estimated model is statistically significant for the level of significance $1 \%(\mathrm{P}$-value $(\mathrm{F})=$ $0.001230<0.01)$.

\subsection{Results of fixed effects model}

The second evaluated model is one of the fixed effects that test, the differences in behavior among states in terms of the influence of independent variables. Also in this model, four independent variables are initially included and after the necessary tests, we come to the best model that is presented in Table 2.

As presented in Table 2, unlike the general panel model, the fixed-effect model displays statistically importance for the level of significance $5 \%(\mathrm{p}=0.0457<0.05)$ and FDI impact (with a 2-year time delay) on the economic growth of the Western Balkans countries, alongside Cap and Gov which also remain with an important statistical impact. In this case, the government expenditures (Gov) increase the significance from a $5 \%$ level in the previous model to $1 \%$ in the current model.

The test on the difference among the interception of states results also as significant $(\mathrm{p}=0.0161<0.01)$ which shows sufficient evidence for accepting alternative hypothesis which ays that there are differences in the behavior among the states, respectively, the intercepts of the model among them are not the same. Subsequently, in the general pattern of the fixed effects, the variables have a significant impact on economic growth, as the differences between countries are meaningful, while economic growth does not depend on the same variables for all countries.

\subsection{Results of random effects (GLS) model}

Also, in the next GLS model where the random effects test (Table 3) is used, whereas previously explained the difference between individuals (states) is not based on interception but rather in the variance of the error term, a significant influence of three independent variables in the dependent variable is evident, roughly the same as in the previous model. Here too the export variable (Ex) is removed from the model.

In Table 3, we see that apart from the significance of all three independent variables on the dependent variable, also the test with the Method LM (Breusch-Pagan test) results significant for the level of importance 5\% $(\mathrm{p}=0.0331339<$ $0.05)$, which means that among the countries there are significant differences on variance.

Table 1. Pool model of estimating FDI impact in the economic growth of the Western Balkans

\begin{tabular}{cccccc}
\hline Dependent variable: GDPgr & Coefficient & Std. Error & t-ratio & p-value & \\
\hline const & -2.01003 & 1.41664 & -1.419 & 0.1608 & \\
\hline RFDI_2 & $3.62675 \mathrm{e}-010$ & $2.49739 \mathrm{e}-010$ & 1.452 & 0.1513 & \\
\hline Cap & 0.182361 & 0.0550405 & 3.313 & 0.0015 & $* * *$ \\
\hline Gov & 0.203947 & 0.0804994 & 2.534 & 0.0138 & $* *$ \\
\hline
\end{tabular}

R-squared 0.217651; Adjusted R-squared 0.180979; F(3, 64) 5.934987 P-value(F) 0.001230 Source: WB (2018) - Processing through Gretl

Table 2. Panel model of fix effects

\begin{tabular}{cccccc}
\hline Dependent variable: GDPgr & Coefficient & Std. Error & t-ratio & p-value & \\
\hline const & -2.11591 & 1.33108 & -1.590 & 0.1173 & \\
\hline RFDI_2 & $4.74612 \mathrm{e}-010$ & $2.44354 \mathrm{e}-010$ & 2.038 & 0.0457 & $* *$ \\
\hline Cap & 0.180540 & 0.0515961 & 3.499 & 0.0009 & $* * *$ \\
\hline Gov & 0.247540 & 0.0772420 & 3.205 & 0.0022 & $* * *$ \\
\hline LSDV R-squared $=0.372495 ;$ Within R-squared $=0.282227 ;$ & P-value $(\mathrm{F})=0.000341$ \\
Test for differing group intercepts - \\
Null hypothesis: The groups have a common intercept \\
Test statistic: $\mathrm{F}(5,59)=2.91179$ \\
with p-value $=\mathrm{P}(\mathrm{F}(5,59)>2.91179)=0.0204422$ \\
Source: WB (2018) - Processing through Gretl
\end{tabular}

Table 3. Panel model of random effects (GLS)

\begin{tabular}{cccccc}
\hline Dependent variable: GDPgr & Coefficient & Std. Error & z & p-value \\
\hline const & -2.09826 & 1.40042 & -1.498 & 0.1341 \\
\hline RFDI_2 & $4.44818 \mathrm{e}-010$ & $2.38867 \mathrm{e}-010$ & 1.973 & 0.0485 & $* *$ \\
\hline Cap & 0.180829 & 0.0510024 & 3.545 & 0.0004 & $* * *$ \\
\hline Gov & 0.236096 & 0.0758801 & 3.111 & 0.0019 & $* * *$ \\
\hline Breusch-Pagan test - & $\begin{array}{l}\text { Null hypothesis: Variance of the unit-specific error }=0 \\
\text { Asymptotic test statistic: Chi-square (1) = 4.53885 }\end{array}$ & \\
Hausman test - & $\begin{array}{l}\text { with p-value = 0.0331339 } \\
\text { Null hypothesis: GLS estimates are consistent } \\
\text { Asymptotic test statistic: Chi-square (3) = 1.89691 } \\
\text { with p-value = 0.594076 }\end{array}$ \\
\hline Source: $W B(2018)$ - Processing through Gretl
\end{tabular}


As stated above, and referring also to authors Gujarati [28] and Osmani [27] as well as in the Gretl test, then we take on the GLS model for case effects, as a model by which we test the hypotheses raised concerning (i) the impact of FDI on the economic growth of the countries of the region and (ii) that there are significant statistical differences between the countries of the Western Balkans regarding the FDI impact.

\subsection{Results of hypothesis testing}

Based on the GLS model, we have sufficient evidence to accept the hypothesis $\mathrm{H}_{1}$ that "FDI has a positive impact on the economic growth of the region (Western Balkans)".

The model also provides sufficient evidence to accept the $\mathrm{H}_{2}$ hypothesis that there are differences between countries in the region as regards the factors affecting economic growth, including FDI.

\section{CONCLUSIONS}

Based on the results of this research we conclude that FDI, in general, has a significant impact on the macroeconomic indicators of the countries in the region. The results are in line with the OECD (2002) finding that large numbers of studies consider that foreign direct investment generates economic growth in the host country. The results show that the effect of FDI on the economic growth of the countries of the region appears two years later than the time of realization of investments.

However, the GLS model data show that there is a difference between the countries of the region in terms of FDI's impact on economic growth. Second hypothesis testing shows that despite the proximity and the similar history, there are differences between these countries, which may be related to their different progress in regard to development policies, facilitation for doing business, and implementation of reforms, respectively the criteria that deal with EU integration. Some of these countries are in the more advanced process of EU integration and some are still in their infancy. Also, the geographical aspect can be a factor that influences the differences that exist between the countries of the region (Albania and Montenegro are coastal countries, Bosnia and Herzegovina has little access to the sea while Kosovo, Northern Macedonia, and Serbia have no access to the sea).

The research has its limitations especially in terms of the time that has been taken in the research due to the lack of data for an earlier period. The longer period of data would enable us to have even more stable results.

These results imply further researches that will focus on identifying differences between countries in the region and the factors that determine these differences in terms of the impact of FDI on macroeconomic indicators, such as geographical factors or the stage of the integration process. Researches can also be oriented to see if the level of development varies so much that it affects the different effects of FDI on these countries. Especially for the fact that several researches, conclude that, let says in Kosovo, FDI has a significant positive impact on economic growth [24], while Kosovo itself is at the lowest level of development compared to the countries of the region.

However, the results are important from the general point of view of the region, both in economic terms and moreover in the political aspect in order to stabilize and sustainable development. As Wang, Li and Sun [21] conclude, many noneconomic factors, such as policies and institutions, now play an important role in FDI inflow. Therefore, the countries of the region must identify their potential and adopt appropriate policies to attract FDI. This is recommended to be done by increasing regional cooperation through joint economic initiatives as it is about small countries. They also need to build capacity to benefit more through supportive policies, especially from the EU, in order to accelerate and facilitate the path to EU integration. This would make these countries more attractive to attract multinational companies to invest in the region and at the same time dilute the negative effect of the conflicting past.

\section{REFERENCES}

[1] Moosa, I.A. (2002). Foreign Direct Investment Theory, Evidence, and Practice. Palgrave Macmillan UK. https://doi.org/10.1057/9781403907493

[2] Alfaro, L. (2015). Foreign Direct Investment: Effects, Complementarities, and Promotion. Chap. 2 in Partners or Creditors? Attracting Foreign Investment and Productive Development to Central America and Dominican Republic, edited by Osmel Manzano, Sebastián Auguste, and Mario Cuevas, 21-76. InterAmerican Development Bank. https://publications.iadb.org/publications/english/docum ent/Partners-or-Creditors-Attracting-Foreign-

Investment-and-Productive-Development-to-CentralAmerica-and-Dominican-Republic.pdf.

[3] Iamsiraroj, S. (2016). The foreign direct investmenteconomic growth nexus. International Review of Economics \& Finance, Elsevier, 42(C): 116-133. https://doi.org/10.1016/j.iref.2015.10.044

[4] Hayat, A. (2018). FDI and economic growth: The role of natural resources? Journal of Economic Studies, 45(2): 283-295. https://doi.org/10.1108/jes-05-2015-0082

[5] Pekarskiene, I., Susniene, R. (2015). Features of foreign direct investment in the context of globalization. Procedia-Social and Behavioral Sciences, 213: 204-210. https://doi.org/10.1016/j.sbspro.2015.11.427

[6] Al-Rodhan, N.R., Stoudmann, G. (2006). Definitions of globalization: A comprehensive overview and a proposed definition. Program on the Geopolitical Implications of Globalization and Transnational Security, 6: 1-21.

[7] OECD. (2010). Measuring Globalisation: OECD Economic Globalisation Indicators 2010, Paris. Raportul Comisiei Europene (2010) Raportul Comisiei Europene privind Fondurile Europene 2007-2010. https://doi.org/10.1787/9789264084360-en

[8] OECD. (2002). Foreign direct investment for development. maximizing benefits, minimizing costs. Overview. Paris: OECD Publications. https://www.oecd.org/investment/investmentfordevelop ment/foreigndirectinvestmentfordevelopmentmaximisin gbenefitsminimisingcosts.htm.

[9] Blomström, M., Kokko, A. (1998). Multinational corporations and spillovers. Journal of Economic Surveys, 12(3): 247-277. https://doi.org/10.1111/14676419.00056

[10] Berthélemy, J.C., Démurger, S. (2000). Foreign direct investment and economic growth: theory and application 
to China. Review of Development Economics, 4(2): 140155. https://doi.org/10.1111/1467-9361.00083

[11] Pessoa, A. (2007). FDI and host country productivity: a review. FEP Working Papers 251. Universidade do Porto, Faculdade de Economia do Porto. http://wps.fep.up.pt/wps/wp251.pdf.

[12] Ribakova, E., Horváth, B., Demekas, D.G., Wu, Y. (2005). Foreign direct investment in southeastern europe: how (and how much) can policies help? IMF Working Paper, $\mathrm{WP} / 05 / 110$ https://doi.org/10.5089/9781451861297.001

[13] Zhang, K.H. (2001). Does foreign direct investment promote economic growth? Evidence from east Asia and Latin America. Contemporary Economic Policy, 19(2): $175-185$ https://doi.org/10.1111/j.14657287.2001.tb00059.x

[14] UNCTAD. (2018). The Least Developed Countries Report. https://unctad.org/webflyer/least-developedcountries-report-2018.

[15] Estrin, S., Uvalic, M. (2014). FDI into transition economies: Are the Balkans different? The Economics of Transition, 22(2): 281-312. https://doi.org/10.1111/ecot.12040

[16] Estrin, S., Uvalic, M. (2016). Foreign direct investment in the western Balkans: What role has it played during transition? Comparative Economic Studies, 58(3): 455483. https://doi.org/10.1057/ces.2016.10

[17] Christie, E. (2003). Foreign direct investment in Southeast Europe. WIIW Working Paper No. 24, The Vienna Institute for International Economic Studies, Vienna.

[18] Brada, J.C., Kutan, A.M., Yigit, T.M. (2004). The effects of transition and political instability on foreign direct investment inflows: Central Europe and the Balkans. William Davidson Institute Working Paper, No.729. https://doi.org/10.2139/ssrn.665122

[19] Topxhiu, R.M., Radoniqi, D.K. (2018). Foreign direct investment and economic growth: Empirical evidence from the west Balkan countries. Journal of Academic Research in Economics, 1. http://www.jaresh.com/downloads/jul_2018/topxhiu.pdf.

[20] CNUCED. (2018). World investment report 2018: Investment and new industrial policies. UN, 2018. https://unctad.org/system/files/officialdocument/wir2018_overview_en.pdf.

[21] Wang, J., Li, Z.D., Sun, X.Y. (2020). Empirical analysis on the influence of business environment on foreign direct investment inflow based on the panel data on 26 countries. International Journal of Sustainable Development and Planning, 15(8): 1223-1230. https://doi.org/10.18280/ijsdp.150808

[22] Dinh, T.T.H., Vo, D.H., Nguyen, T.C. (2019). Foreign direct investment and economic growth in the short run and long run: Empirical evidence from developing countries. Journal of Risk and Financial Management, 12(4): 176. https://doi.org/10.3390/jrfm12040176

[23] Vasa, L., Angeloska, A. (2020). Foreign direct investment in the Republic of Serbia: correlation between foreign direct investments and the selected economic variables. J. Int. Stud., 13(1): 170-183. https://doi.org/10.14254/2071-8330.2020/13-1/11

[24] Shodra, N., Sopi, X., Pantina, M.B. (2019). The effect of foreign direct investment in transition countries - case of Kosovo. Advances in Business-Related Scientific Research Journal (ABSRJ), 10(1): 13-21.

[25] Solow, R. (1956). A contribution to the theory of economic growth. Quarterly Journal of Economics, 70(1): 65-94. https://doi.org/10.2307/1884513

[26] Studenmund, A.H. (2017). A Practical Guide to Using Econometrics (7 ed. Global edition). Pearson Education Limited.

[27] Osmani, M. (2013). Econometric Methods with Eviews. Maluka, Tiranë.

[28] Gujarati, D.N. (2004). Basic Econometrics (fourth edition). The McGraw-Hill Companies.

[29] Dalei, N.N. (2016). Determinants of energy consumption in open economies. Contemporary Issues in Trade, Environment, and Policy, 89-104. https://www.researchgate.net/publication/306099265_D eterminants_of_Energy_Consumption_in_Open_Econo mies.

[30] Goschin, Z. (2014). Remittances as an economic development factor. Empirical evidence from the CEE countries. Procedia Economics and Finance, 10: 54-60. https://doi.org/10.1016/S2212-5671(14)00277-9

[31] Meyer, D., Shera, A. (2017). The impact of remittances on economic growth: An econometric model. Economi A, 18(2): 147-155. https://doi.org/10.1016/j.econ.2016.06.001

[32] Choe, J.I. (2003). Do foreign direct investment and gross domestic investment promote economic growth? Review of Development Economics, 7(1): 44-57. https://doi.org/10.1111/1467-9361.00174

[33] WB. (2019). World Development Indicator. Washington DC: World Bank. https://data.worldbank.org/indicator.

[34] Żuk, P., Savelin, L. (2018). Real convergence in central, eastern and south-eastern Europe. ECB Occasional Paper, No. 212, European Central Bank (ECB). http://dx.doi.org/10.2866/747750

[35] World Bank Group. (2018). Western Balkans Regular Economic Report. no. 14. https://thedocs.worldbank.org/en/doc/19430153865099 6304-

0080022018/original/rev2WBRER14WQwebENG.pdf. 